\title{
An RT-PCR-based method for the diagnosis of the sleeping disease virus in experimentally and naturally infected salmonids
}

\author{
Stéphane Villoing ${ }^{1,2}$, Jeannette Castric ${ }^{2}$, Joëlle Jeffroy ${ }^{2}$, Alain Le Ven ${ }^{2}$, \\ Richard Thiery ${ }^{2}$, Michel Bremont ${ }^{1, *}$ \\ ${ }^{1}$ Unité Virologie et Immunologie moléculaires, Institut National de la Recherche Agronomique, INRA, \\ 78352 Jouy-en-Josas Cedex, France \\ ${ }^{2}$ Laboratoire de Pathologie des Animaux Aquatiques, AFSSA Brest Technopole Brest-Iroise, BP 70,29280 Plouzané, France
}

\begin{abstract}
The sleeping disease (SD) of rainbow trout (Oncorhynchus mykiss) is a worldwide disease for which the causative agent, the sleeping disease virus (SDV), has been recently characterized as an atypical alphavirus (Villoing et al. 2000). Up to now, no diagnostic tools were available and thus no epidemiological studies have been undertaken to evaluate the occurrence of this disease on the field. We present in this paper a sensitive and highly specific 1 working day method, which allows the detection of SDV from experimentally and naturally infected fishes. This method, based on a reverse transcriptase/polymerase chain reaction (RT-PCR) assay on total RNA extracted from SDV-infected fish organs, enables the specific DNA amplification of part of the gene encoding the SDV glycoprotein E2, as early as $2 \mathrm{~d}$ post-infection (d.p.i.) and as late as $70 \mathrm{~d}$.p.i., at which time clinical signs of infection are no longer apparent. Moreover, we show that this RT-PCR method can be successfully used for the diagnosis of fish infected by a closely related virus, namely salmon pancreas disease virus (SPDV). This report is the first description of a very powerful diagnostic assay which could provide a more accurate replacement for the classical virological, histological and immunochemistry methods.
\end{abstract}

KEY WORDS: Sleeping disease virus - Salmon pancreas disease virus - Alphavirus - Rainbow trout Salmon $\cdot$ RT-PCR $\cdot$ Diagnosis

\section{INTRODUCTION}

Sleeping disease (SD) syndrome of freshwater farmed rainbow trout has been observed in France for many years (Boucher \& Baudin-Laurencin 1994). The most characteristic sign of the disease is the unusual behavior of fish, which stay on their side at the bottom of the tank. Through experimental SD transmission assay, the sequential histology of this disease has been studied (Boucher et al. 1995), and it was revealed that infected fishes successively developed pancreatic, cardiac, and muscular lesions. A viral etiology of SD was suspected (Boucher et al. 1994) and thereafter confirmed by the isolation of a virus, the sleeping disease

•Corresponding author. E-mail: bremont@biotec.jouy.inra.fr virus (SDV) by the inoculation of organ homogenates from diseased fish to cell cultures (Castric et al. 1997). cDNA cloning and nucleotide sequencing of part of the SDV RNA genome has permitted us to assign SDV to the alphavirus, an important genus of the Togaviridae (Villoing et al. 2000).

To date, SD is only diagnosed following observation of clinical signs of fishes thought to be infected, and by the implementation of various methods such as virological assay in cell culture or histological studies. A virological assay is time consuming and not always reliable, a major limitation being the fact that the virus must be adapted to grow in cell culture. Histological studies of SDV-infected fish tissues are unable to discriminate between fish infected by SDV from those infected by the infectious pancreatic necrosis virus (IPNV), a birnavirus which induces the same kind of 
lesions in juvenile rainbow trouts. To prevent future $\mathrm{SD}$ outbreaks and further spread of this disease in fish farms, an early and reliable viral detection method appears necessary, since to date, there are no effective therapeutics against SD.

The use of a reverse transcription and polymerase chain reaction (RT-PCR) assay for the sensitive detection of RNA viruses has been developed for a number of fish viruses such as IPNV (Lopez-Lastra et al. 1994, Blake et al. 1995, Suzuki et al. 1997), nodaviruses (Nishizawa et al. 1994, Péducasse et al. 1999) and fish rhabdoviruses (Bruchhof et al. 1995, Miller et al. 1998, Guillou et al. 1999). We have investigated the usefulness of an RT-PCR method for the diagnosis of experimentally or naturally SDV-infected rainbow trout and compared the results with those obtained in parallel with virological, histological and immunohistological techniques. We demonstrate in this report the superiority, in terms of sensitivity and specificity, of the RT-PCR method compared to the other methods tested. Furthermore, we have also assessed the usefulness of this method for the early detection of a closely SDV-related virus, namely the salmon pancreas disease virus (SPDV), in experimentally and naturally infected salmons.

\section{MATERIALS AND METHODS}

Cells and viruses. Salmonid-derived cell line CHSE214 (Lannan et al. 1984) was maintained in Eagle's minimum essential medium (MEM, Sigma FRANCE) buffered at $\mathrm{pH} 7.4$ with Tris- $\mathrm{HCl}$, supplemented with $10 \%$ fetal bovine serum (FBS, Boehringer-Mannheim, France), 50 I.U. penicillin $\mathrm{ml}^{-1}$ and $50 \mathrm{mg} \mathrm{ml}^{-1}$ of strep- tomycin. Cells were maintained in 75 and $150 \mathrm{~cm}^{2}$ plastic cell culture flasks at $20^{\circ} \mathrm{C}$.

Viruses used for the experimental fish infections were respectively: SDV adapted to grow in CHSE-214 cell culture (strain S49P, $10^{6}$ pfu $\mathrm{ml}^{-1}$ ), a 'wild-type' SDV preparation (an homogenized mixture of kidneys of farmed infected rainbow trouts, $10^{6}$ pfu $\mathrm{ml}^{-1}$ ), SPDV adapted to CHSE-214 cell culture (strain $\mathrm{P} 42 \mathrm{P}, 4.10^{8} \mathrm{pfu}$ $\mathrm{ml}^{-1}$ ). The P42P SPDV strain was originally isolated from kidneys of Atlantic salmon suffering of pancreas disease (kindly provided by Dr McVicar, Marine Laboratory of Aberdeen, UK).

Fish and fish facilities. Juvenile rainbow trout $(0.5 \mathrm{~g})$ used in this study were the progeny of virus-free genitors bred in our fish facilities. Fish were randomly placed in $50 \mathrm{l}$ (volume of water: 30 l) aerated tanks, with opened circulation of filtered and UV-sterilised freshwater at a controlled temperature of $10 \pm 1^{\circ} \mathrm{C}$. Commercial food was manually distributed twice a day. Others fish samples used in this study originated from different French fish farms where SD outbreaks were suspected (Table 1).

Experimental infections. Experimental infections were conducted as follow: 600 virus-free juvenile rainbow trout were infected by static immersion with S49P SDV strain (final titer: 1 to $2.10^{4} \mathrm{pfu} \mathrm{ml}^{-1}$ ) during $2 \mathrm{~h}$ at $10^{\circ} \mathrm{C}\left( \pm 2^{\circ} \mathrm{C}\right)$ in an aquarium filled with $3 \mathrm{l}$ of river freshwater. Fish were then transferred to an aquarium filled with $30 \mathrm{l}$ of freshwater. As a control, 600 virusfree juvenile rainbow trout were mock-infected with cell culture medium in the same conditions. Similar experimental infections were also done using 'wildtype' SDV (final titer: $10^{4} \mathrm{pfu} \mathrm{m}^{-1}$ ) and P42P SPDV strain (final titer: 1 to $2.10^{4} \mathrm{pfu} \mathrm{m}^{-1}$ ).

Table 1. Fish samples used in study taken from fish farms where SD outbreaks were suspected. Average freshwater temperature in tanks at sampling time: $14 \pm 2^{\circ} \mathrm{C}$

\begin{tabular}{|c|c|c|c|c|}
\hline $\begin{array}{l}\text { Sample } \\
\text { reference no. }\end{array}$ & $\begin{array}{l}\text { Sample } \\
\text { (no. of fish) }\end{array}$ & Sampling date & $\begin{array}{l}\text { Body weight } \\
\qquad(\mathrm{g})\end{array}$ & Symptoms and observations \\
\hline 9085 & Rainbow trout (11) & 14 April 1999 & $150-250$ & $\begin{array}{l}6 \text { fish with SD-like symptoms (less appetite, swam } \\
\text { or stayed on their side). } 5 \text { fishes were asymptomatic } \\
\text { although they came from the same tank }\end{array}$ \\
\hline 9101 & Rainbow trout (7) & 19 May 1999 & 25 & Some fish with SD-like symptoms \\
\hline 9106 & Rainbow trout (3) & 20 May 1999 & 700 & Potential SD-like symptoms; lesions on the flank \\
\hline 9108 & $\begin{array}{l}\text { Rainbow trout } \\
\text { ( } 12 \text {, plus } 5 \text { fishes fixed } \\
\text { in } 10 \% \text { formaldehyde) }\end{array}$ & 26 May 1999 & 25 & $\begin{array}{l}7 \text { fish with SD-like symptoms. } 5 \text { asymptomatic fish, } \\
\text { although they came from the same tank }\end{array}$ \\
\hline 9109 & $\begin{array}{l}\text { Rainbow trout } \\
\text { ( } 7 . \text { plus } 5 \text { fishes fixed } \\
\text { in } 10 \% \text { formaldehyde) }\end{array}$ & 26 May 1999 & 25 & $\begin{array}{l}\text { Fish stayed on their side at the bottom of the } \\
\text { tank. Low mortality observed }\end{array}$ \\
\hline 9115 & Rainbow trout $(6)$ & 31 May 1999 & 50 & $\begin{array}{l}\text { Fish had less appetite and growth stop for } 3 w k \text {, } \\
\text { but they returned to a healthy state }\end{array}$ \\
\hline 9127 & Salmo salar (4) & 9.June 1999 & 50 & $\begin{array}{l}\text { Less appetite could be observed, and these fish } \\
\text { usually swam at the bottom of the tank }\end{array}$ \\
\hline
\end{tabular}


Sampling and analysing protocol. For each assay, 30 infected and 6 mock-infected fish were randomly collected at various days post infection (d.p.i.) (from 2 to 41). For wild type SDV strain, fish were also collected at 70 d.p.i. At each sampling time, 10 infected and 2 mockinfected fish were analysed by the RT-PCR-based SDV detection method, 10 infected and 2 mock-infected fish were analysed by virological titering, and the remaining 10 infected and 2 mock-infected fish were analysed by histopathology and immunohistochemistry (IHC).

Preparation of total RNA from fish. Total RNA from fish was extracted using the RNA Now ${ }^{\mathrm{TM}}$ (Biogentex, USA) procedure. Briefly, fish were crushed in a Dounce homogenizer in a $2 \mathrm{ml}$ tube containing $1 \mathrm{ml}$ of RNA Now lysis buffer. Chloroform $(0.2 \mathrm{ml})$ was added, and the obtained mixture was left on ice for $5 \mathrm{~min}$. It was then centrifuged at $14000 \mathrm{rpm}(20000 \times \mathrm{g})$ for $10 \mathrm{~min}$. The aqueous phase containing RNA was transferred to a new tube, and an equal volume of isopropanol was added. After $1 \mathrm{~h}$ at $-20^{\circ} \mathrm{C}$, the tubes were centrifuged at $14000 \mathrm{rpm}(20000 \times \mathrm{g})$ for $10 \mathrm{~min}$. The RNA pellets were washed with ice-cold $70 \%$ ethanol for $5 \mathrm{~min}$, and the pellets were dried $5 \mathrm{~min}$ in a concentrator (Speedvac, Savant). Dried RNA pellets were then resuspended in $700 \mu \mathrm{l}$ DEPC-treated water. When RNA was extracted from individual fish organs (caeca, kidney, brains, heart), the RNA pellets were resuspended in $300 \mu \mathrm{l}$

Total RNA preparation from SDV or SPDV-infected cells. SDV was grown in 10 flasks $\left(150 \mathrm{~cm}^{2}\right)$ containing RTG-2 cells for $10 \mathrm{~d}$ at $10^{\circ} \mathrm{C}$. Flasks were placed at $-80^{\circ} \mathrm{C}$ for $3 \mathrm{~h}$, then a pool of scraped cells supernatant was centrifuged at $35000 \mathrm{rpm}(150000 \times \mathrm{g})$ for $90 \mathrm{~min}$. Pellets were resuspended in $500 \mu l$ of Eagle-Tris medium and RNA was extracted using the QIAAMP viral RNA extraction kit (Qiagen, France), and the RNA was recovered in $50 \mu \mathrm{l}$ of DEPC-treated water. The same procedure was used to recover SPDV RNA, except that SPDV was grown on CHSE-214 cells at $14^{\circ} \mathrm{C}$.

RT-PCR. cDNA synthesis and DNA amplification were done using primers derived from the published SDV nucleotide sequence (Villoing et al. 2000, accession number AJ238578). Two microliters of extracted RNAs were added to $18 \mu \mathrm{l}$ of a reverse transcription (RT) mixture containing: $10 \mathrm{mM}$ Tris $\mathrm{HCl}, \mathrm{pH} 8.3$, $50 \mathrm{mM} \mathrm{KCl}, 5 \mathrm{mM} \mathrm{MgCl}, 1 \mathrm{mM}$ dNTP and $20 \mathrm{pmol}$ of the primer SDV3' (position 2016-2044, 5'-GGATCCATTCAGATGTGGCGTTGCTATGG-3') (Genset, France). RNA was denatured for $5 \mathrm{~min}$ at $99^{\circ} \mathrm{C}$ and 50 units of MuLV reverse transcriptase (Perkin Elmer) were added. The reaction was incubated for $30 \mathrm{~min}$ at $42^{\circ} \mathrm{C}$; then MuLV was denaturated at $95^{\circ} \mathrm{C}$ for $10 \mathrm{~min}$. To the RT reaction tube, $80 \mu \mathrm{l}$ of a PCR mixture containing $10 \mathrm{mM}$ Tris $\mathrm{HCl}, \mathrm{pH} 8.3,50 \mathrm{mM} \mathrm{KCl}, 1.5 \mathrm{mM} \mathrm{MgCl}_{2}$, and $10 \mathrm{pmol}$ of the forward primer SDV5' (position
1740-1767, 5'-CGTGACCTTCACCAGCGACTCCCAGACG-3') (Genset, France) were added, and the mixture was heated for $2 \mathrm{~min}$ at $94^{\circ} \mathrm{C}$ and 2.5 units Taq DNA polymerase (Promega) were added (hot-start). PCR was performed with the following conditions: one step at $94^{\circ} \mathrm{C}$ for $2 \mathrm{~min}$, then 5 cycles at $94^{\circ} \mathrm{C}$ for $40 \mathrm{~s}$, $57^{\circ} \mathrm{C}$ for $30 \mathrm{~s}$ and $72^{\circ} \mathrm{C}$ for $30 \mathrm{~s}$, then 35 cycles at $94^{\circ} \mathrm{C}$ for $40 \mathrm{~s}, 65^{\circ} \mathrm{C}$ for $30 \mathrm{~s}$ and $72^{\circ} \mathrm{C}$ for $30 \mathrm{~s}$, then a final extension step at $72^{\circ} \mathrm{C}$ for $7 \mathrm{~min}$. PCR products $(15 \mu \mathrm{l})$ were analysed by electrophoresis on a $1.5 \%$ agarose gel.

PCR products sequencing. PCR products were purified using the high pure PCR product purification kit (Boehringer-Mannheim, France) according to the manufacturer's recommendations. Nucleotide sequencing reactions of $R T$-PCR products were carried out on a $\mathrm{ABI} 377 \mathrm{~A}$ DNA automatic sequencer using the $\mathrm{ABI}$ Prism dye deoxy terminator prism kit (Applied Biosytem, Division of Perkin-Elmer, France).

Virological examination. Fish or organs were homogenized in a mortar with a pestle and sea sand in 9 volumes of Eagle's solution containing penicillin (200 I.U. ml $\left.{ }^{-1}\right)$, streptomycin $\left(0.2 \mathrm{mg} \mathrm{ml}^{-1}\right)$ and kanamycin $\left(0.2 \mathrm{mg} \mathrm{ml}^{-1}\right)$. After centrifugation at $2000 \times g$ for $15 \mathrm{~min}$ at $4^{\circ} \mathrm{C}$, the supernatant was passed through a membrane filter $(0.45 \mu \mathrm{M})$ and was inoculated on CHSE-214 cells. Inoculated cells were incubated at $10^{\circ} \mathrm{C}$ (SDV) or $14^{\circ} \mathrm{C}$ (SPDV) for $7 \mathrm{~d}$; then plaques were directly counted when the SDV S49P strain or P42P SPDV were used. For the wild type SDV, a reverse plaque titration assay was performed: serial SDV dilutions in MEM (from $10^{2}$ to $10^{12}$ ) were prepared and inoculated in duplicate on CHSE-214 cells in 96-well plates. After a $7 \mathrm{~d}$ incubation at $14^{\circ} \mathrm{C}$, infected cells were over-infected with the viral hemorrhagic septicemia virus, VHSV, (500 pfu well ${ }^{-1}$ ). After 3 d, cells were fixed with formalin and stained with violet crystal.

Histological assessment and immunohistochemistry assays. Fish were killed and fixed in Bouin's fixative, dehydrated through graded ethanol xylene baths and embedded in parafin (Gabe 1968). Sections (containing pancreas, heart, muscles and brains) of 5 to $6 \mu \mathrm{m}$ were first deparaffinised, rehydrated and then stained with haematoxylin-eosin (HE) for histopathological examination. For the immunochemistry assays, the slides were first incubated for $5 \mathrm{~min}$ in hydrogen peroxide ( $3 \%$ in distillated water) to block the endogenous peroxidase activity. Following washes in PBS, the slides were saturated in PBSA ( $3 \% \mathrm{BSA}$ in PBS) and incubated for $1 \mathrm{~h}$ with a 1:100 dilution of a rabbit polyclonal anti-E2 SDV antiserum (Villoing et al. 2000). Following 2 washes in PBS-Tween (1\% Tween 20 in PBS) and 1 wash in PBS, slides were incubated for 30 min with an anti-rabbit IgG goat antibody conjugated with peroxidase (dilution 1:100). After washes, the peroxidase substrate solution (AEC chromogen, 
Sigma, France) was added for $10 \mathrm{~min}$. Following washes in distilled water, samples were counterstained with haemaloxylin and mounted in an aqueous mounting medium (Daido Sangyo Co. Ltd., Japan).

\section{RESULTS}

\section{Assessment of three diagnosis methods on experimentally infected rainbow trout}

Three different viral strains were used to infect juvenile rainbow trouts, respectively: a tissue-culture adapted viral strain of SDV (S49P, Castric et al. 1997), a SDV wild type strain, and a tissue-culture adapted viral strain of SPDV (P42P, Castric unpubl.). From 2 to 41 d.p.i., sampled fishes were sacrified and the detection of virus was determined through (1) virological assay, (2) histological analysis and IHC, and (3) RT-PCR.

\section{Virological analysis}

As shown in the Fig. 1, virological assays detected infected fish from 2 to 41 d.p.i., with some variations depending on the viral strain used for the infection trials. The maximum viral titers in fish were obtained at 21 d.p.i. (10 $10^{9.3} \mathrm{pfu}^{-1}$ organ) and and the cumulative rate of positive fish was $75 \%$. For the wild type SDV strain, the maximum viral titer was $10^{65} \mathrm{pfu}^{-1}$ organ at 9 d.p.i., and the cumulative rate of positive fish was $77 \%$. For the SPDV strain, titer reached a maximum of $10^{8.4} \mathrm{pfu} \mathrm{g}^{-1}$ organ at $14 \mathrm{~d}$.p.i., and the cumulative rate of positive fish was $70 \%$.

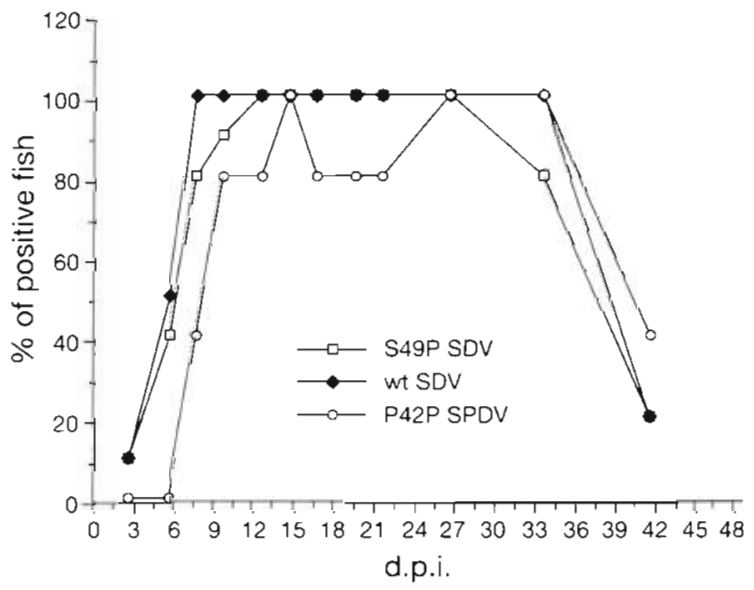

Fig. 1. Detection of SDV and SPDV in experimentally infected fish by a virological assay. Fish samples were taken and analysed at various days post-infection (d.p.i.) by the virological assay as described in 'Materials and methods'. Virus strains used for the infection trials are indicated in the upper right part of the graph. wt: wild type
Virological assay was also used to detect separately virus extracted from fish brain and organs. A typical result obtained with fish infccted with the wild type SDV is shown in Fig. 2. From internal organs (body), SDV was recovered in 1 out of 10 fish at 2 d.p.i., and then 50 to $100 \%$ of the fish were positive from 5 to 21 d.p.i. From 26 to 41 d.p.i., no more virus was recovered from the body. Interestingly, when the brain (head) was used as starting material, the earliest time of detection of SDV was at 5 d.p.i. in 1 out of 10 fish, then culminated untill 31 d.p.i., and was detected up to 41 d.p.i. in 2 fishes. Maximum viral titer was observed in brains at 9 d.p.i. ( $10^{6.5} \mathrm{pfu} \mathrm{g}^{-1}$ organ). At 70 d.p.i., no virus was detected any longer using the virological method, either from brains or internal organs (data not shown). The overall detection rate with fish infected by the wild type SDV was 77 and $63 \%$ from brains and internal organs, respectively.

When a similar experiment was conducted with SPDVinfected fish, the data were superimposable on those obtained with SDV-infected fish (not shown).

Virological assay was also conducted with 2 fish farm samples: one sample consisted of farmed rainbow trout (sample reference 9085) for which internal organs had been analysed, but no virus found. The other samples analysed were farmed Atlantic salmon (sample reference 9127), and virus was found in the internal organs in only 1 out of the 4 salmon analysed (viral titer $10^{3} \mathrm{pfu}^{-1}$ organ), but the nature of this virus (SDV or SPDV) could not be determined by the virological procedure.

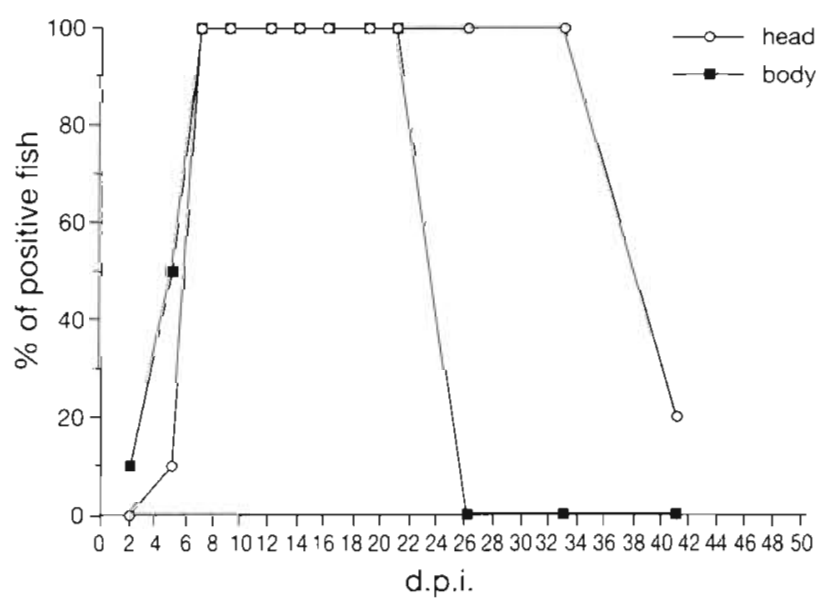

Fig. 2. Virological assay on brain and internal organs from the wild type (wt) SDV-infected rainbow trout. Rainbow trout were infected with wt SDV strain and samples were taken and analysed at various days post-infection (d.p.i) by the virological assay as described in 'Materials and methods' Cell culture were innoculated with homogenates of either brains (head) or internal organs (body) as indicated in the upper right part of the graph 


\section{Histopathological and IHC assays}

Through histopathological and IHC studies, the earliest time of noticeable changes in infected fish was at 7 d.p.i., when the S49P and the wild type SDV strain as well were used (Fig. 3) and only at 13 d.p.i. for the SPDV. Striking histopathological changes were observed in some fish until 41 d.p.i. for each virus strain. Characteristic SD lesions in the pancreas, which is the primary organ damaged in the histological course of $\mathrm{SD}$, and fish with an IHC-positive pancreas could be seen (Fig. 4) from the earliest stage of infection and afterwards. The IHC method gave a detection rate of $35 \%$ with the S49P SDV strain, but was much lower with the wild type SDV and SPDV strains, 3 and $10 \%$ respectively. However, IHC-positive fish were not observed any more after 21 d.p.i. with any of the viral strains, reflecting probably the regeneration of the pancreas by the inflammatory cells and the remaining unharmed pancreatic tissue (Murphy et al. 1992). Histological and IHC methods have been carried out on the brains of wild type SDV-infected fish, but no positive fish was detected.

Histopathological and IHC studies have been also done on 2 fish farm samples (reference nos. 9108 and 9109), but failed to detect any lesions on the fish tested.

\section{RT-PCR assays}

Fig. 5 presents the data obtained for virus detection in experimentally infected fish when a RT-PCR method was used. The earliest time of virus detection in fish

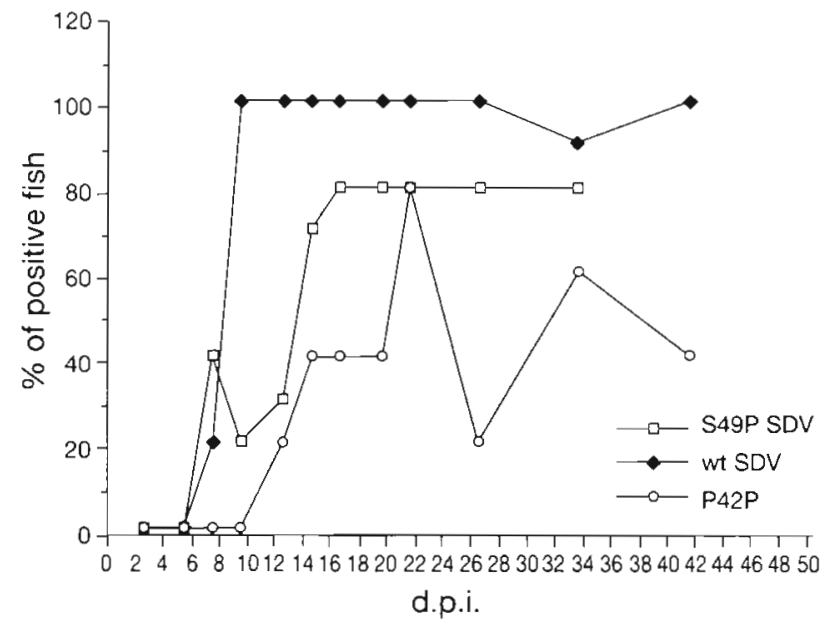

Fig. 3. Analysis of SDV and SPDV-infected fish. Fish samples were taken and analysed at various days post-infection (d.p.i.), by the histopathological and IHC assays as described in 'Materials and methods'. Virus strains used for the infection trials are indicated in the upper right part of the graph. wt: wild type experimentally infected with the S49P strain of SDV was surprisingly late, 7 d.p.i., when compared to the others methods described above. However, when the wild type SDV strain is used, the virus was detected as soon as 2 d.p.i. on $30 \%$ of the infected fish. At longer time post-infections, all the fish were positive independently of the virus strain used, until the last time of sampling (41 d.p.i.). When the wild type SDV strain was used, an additionnal sampling at 70 d.p.i. was done, and virus was still detected, in contrast to the lack of virus detection when others methods were used (data not shown). Fig. 6 shows a typical result of an RT-PCR assay at 16 and 19 d.p.i. where the expected 284 nucleotides (nt) amplification product is present when RNA was extracted from fish infected with the S49P SDV strain.

RT-PCR-based detection method was also tested on experimentally SPDV-infected rainbow trout. As a preliminary step, RT-PCR was performed with total RNA extracted from SDV or SPDV-infected cells, and the nucleotide sequences of the PCR products were determined. The alignment of the SDV and SPDV PCR products nucleotide sequences emphasized the very high percentage of nucleotide identity between SDV and SPDV in this region (Fig. 7), thus validating the use of the RT-PCR-based method for the detection of SDV and SPDV, as well. RT-PCR carried out on RNA extracted from experimentally SPDV-infected rainbow trout gave positive results from 5 to 41 d.p.i., with an overall positive detection rate of $86 \%$ (data not shown).

The RT-PCR-based detection method was also tested on fish samples originating from 7 fish farms suspected of SDV or SPDV infections. RT-PCR was performed on RNA extracted from various fish organs (pylor caeca, kidney, heart and brain) and the more reliable results were obtained with RNA extracted from caeca or kidneys (Fig. 8). All the farmed rainbow trout and Atlantic salmon analysed were positive following RT-PCR assays. Analysis of the nucleotide sequences of the $284 \mathrm{nt}$ long RT-PCR products indicated that all the positive fishes, rainbow trout and Atlantic salmon, had been infected by SDV.

\section{DISCUSSION}

The aim of this study was to determine which technique, among virological, histology/IHC and RT-PCR techniques, would be the most appropriate for routine diagnosis of SDV or SPDV infections. To evaluate the accuracy of each technique, experimental infections were carried out with different viral strains on juvenile fish, given that they are generally more sensitive to infections with SDV or SPDV. 

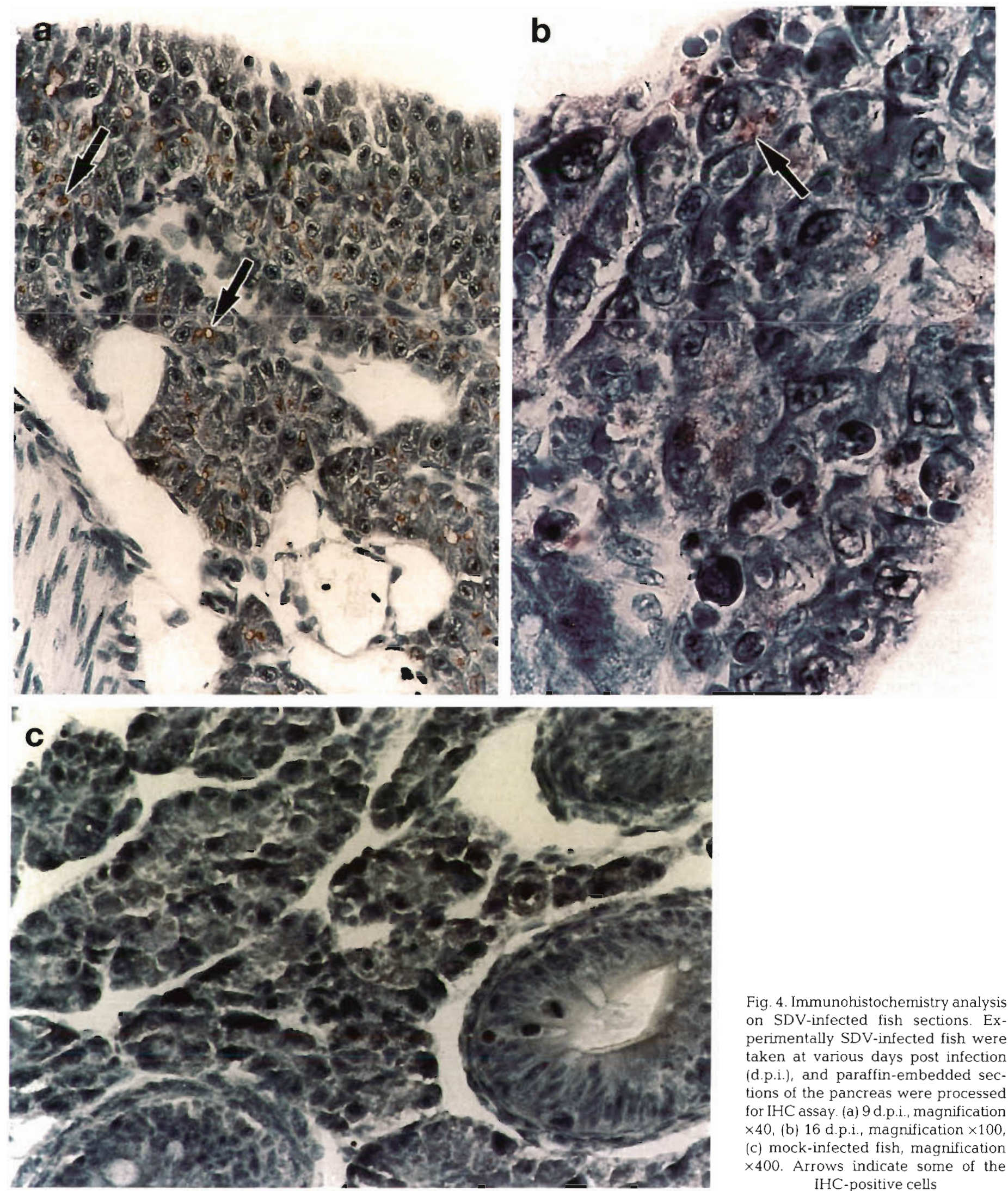

Fig. 4. Immunohistochemistry analysis on SDV-infected fish sections. Experimentally SDV-infected fish were taken at various days post infection (d.p.i.), and paraffin-embedded sections of the pancreas were processed for IHC assay. (a) 9 d.p.i. magnification $\times 40$, (b) 16 d.p.i., magnification $\times 100$, (c) mock-infected fish, magnification $\times 400$. Arrows indicate some of the IHC-positive cells 


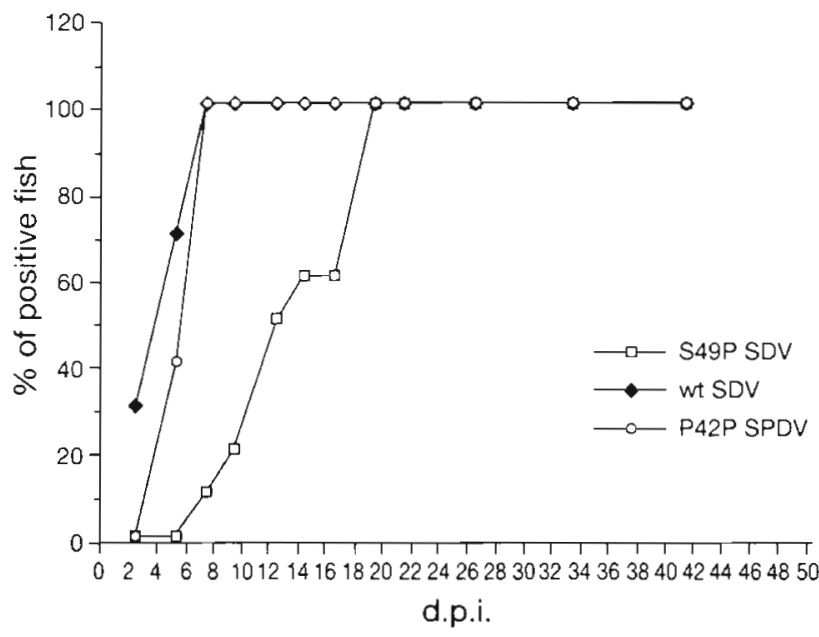

Fig. 5. Detection of SDV and SPDV in experimentally infected fish by a RT-PCR assay. Fish samples were taken and analysed at various days post-infection (d.p.i.) by the RT-PCR assay as described in 'Materials and methods'. Virus strains used for the infection trials are indicated in the upper right part of the graph. wt: wild type

Depending on the virus strain used in this study, data obtained were variable in terms of efficiency of virus detection in infected fish. For example, the virological procedure was more efficient with the cell cultureadapted S49P SDV strain, enabling very early SDV detection, as soon as 2 d.p.i. However, for the wild type SDV strain, which is probably more closely related to the viral strains present in the field, the best results were obtained by the RT-PCR method, which provided the earliest time of detection, and, in most cases enabled the latest detection of the virus up to 70 d.p.i. (data not shown), in contrast to the 2 other methods which did not detect virus at that time. The presence in infected fish of circulating viral neutralizing antibodies, which induce a drastic loss of viral infectivity in cell culture, may explain the absence of positiye detection by the virological or histological and IHC methods at 70 d.p.i. In addition, it has previously been observed in SPDV-infected Atlantic salmon that kidney and plasma become non-infectious when peak pathology occurs (Houghton et al. 1995). Thus, a similar phenomenon may also occur following SDV infections that would explain the sudden decrease in the positive fish detection rate after 33 d.p.i., and also the decrease in viral titers (data not shown). That observation, and the finding that no virus can be detected in fish infected for more than $1 \mathrm{mo}$, emphasize the disadvantage of the virological method as a tool for routine diagnosis. Similarly, at 70 d.p.i., no detection of wild type SDVinfected fish was observed either by the histological or IHC methods, which would seem to imply that it may not be possible to use these methods on a routine basis. Moreover, it is noteworthy that a very low detection

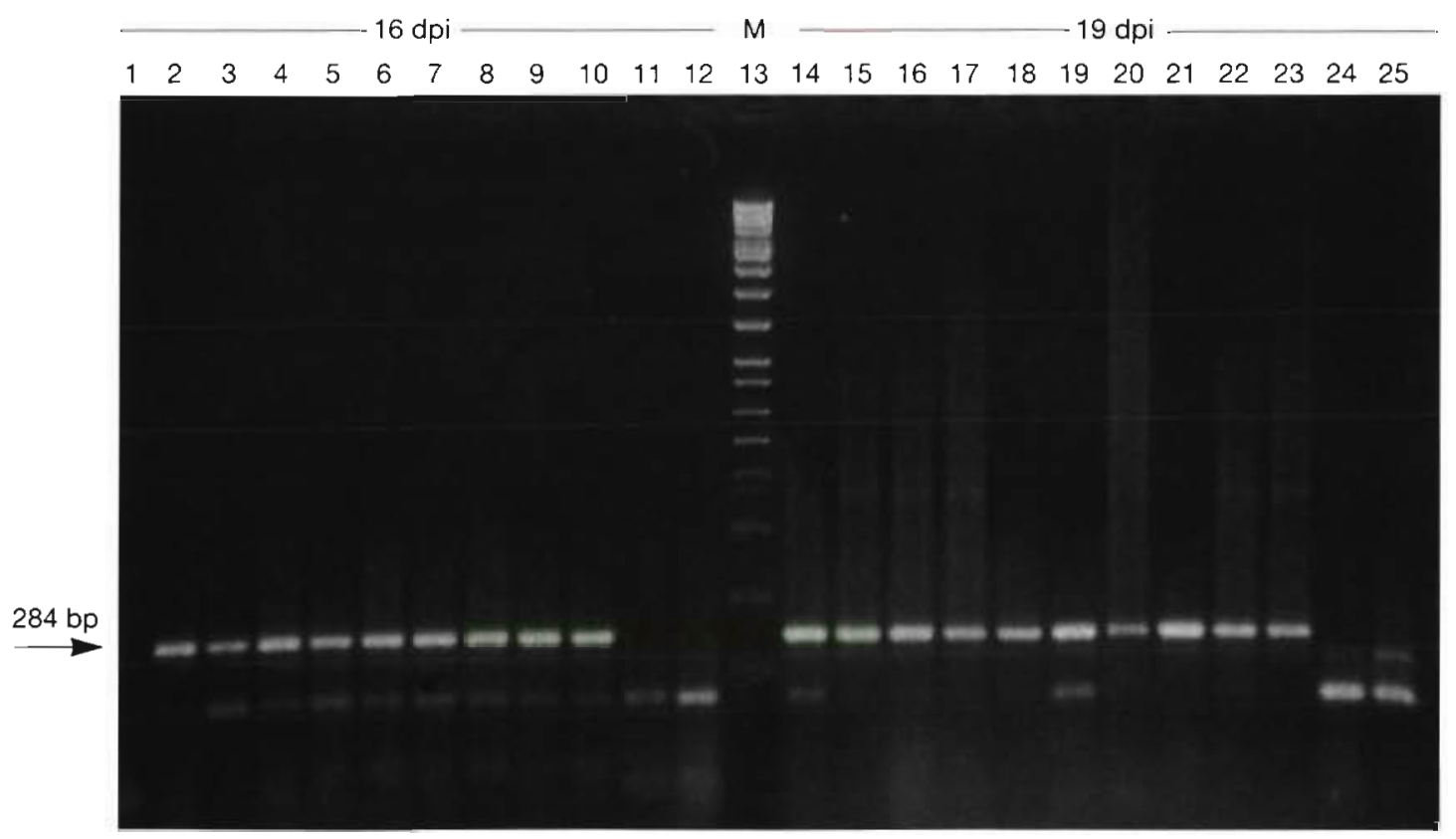

Fig. 6. Detection of SDV by RT-PCR in wild type (wt) SDV-infected fish. Total RNA was extracted from wt SDV-infected fish at 16 or 19 d.p.i. RT-PCR assay was conducted as described in 'Materials and methods'. PCR products were analysed on a $1 \%$ agarose gel and visualized by ethidium bromid staining. Arrow indicates the expected 284 nt PCR product. Lanes 1 to 10 and 14 to 23 : infected fish samples at 16 and 19 d.p.i respectively. Lanes 11 \& 12 and 24 \& 25: mock-infected fish samples at 16 and 19 d.p.i. respectively. Lane 13, M: DNA ladder (Raoul marker, Appligene) 


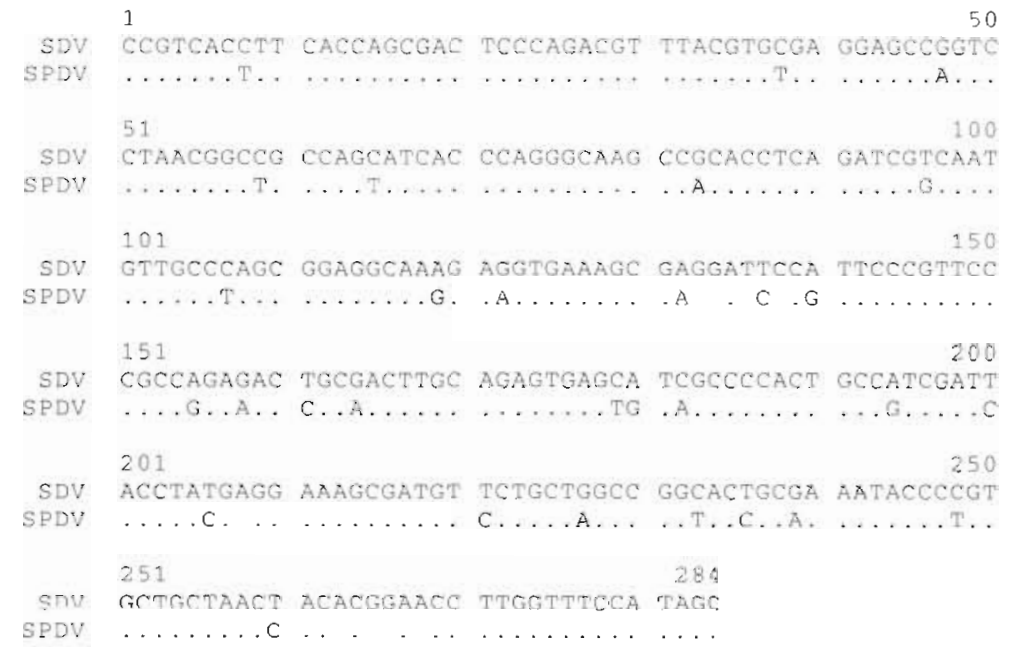

Fig. 7. Comparison of part of the SDV and SPDV E2 gene sequence. The nucleotide sequences of the 284 nt PCR products generated by RT-PCR from total RNA extracted from SDV (upper) and (lower) SPDV-infected cells were compared. Dots indicate identical nucleotides

rate was observed in fish infected with the wild type SDV and the SPDV strain, 3 and 10\% respectively, when the IHC method was used. One probable explanation for this is that the anti-SDV E2 polyclonal antiserum used for immunological detection was raised by immunizing a rabbit with part of the SDV E2 glycoprotein expressed in $E$. coli, and thus this antiserum may not be appropriate to recognize the native SDV (or SPDV) E2 glycoprotein. In the future, the availability of antiserum directed against other SDV structural proteins, such as the capsid protein, may help to increase the detection rate of infected fish by the IHC method.

The ability to detect virus in symptomatic or asymptomatic fish is a crucial criterion for the choice of a

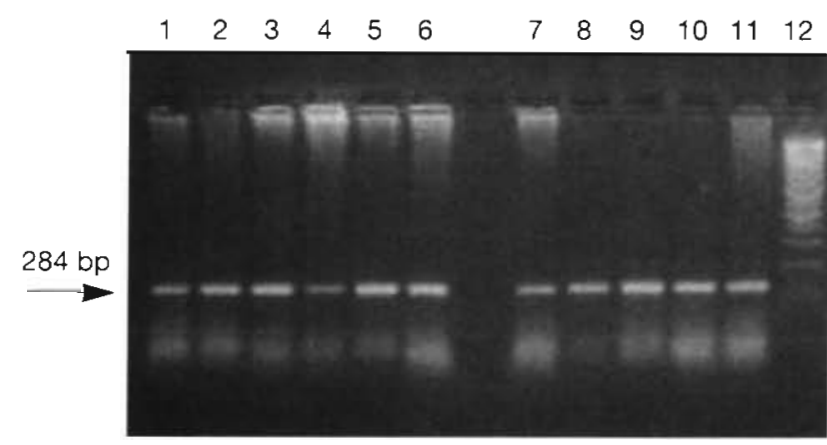

Fig. 8. Detection of SDV by RT-PCR on total RNA from naturally infected fish. RNA was extracted from pyloric caeca from adult rainbow trout originating from a fish farm (sample ref. 9085). RT-PCR assay was conducted as described in 'Materials and methods'. PCR products were analysed on a $1 \%$ agarose gel and visualized by ethidium bromid staining. Arrow indicates the expected 284 nt PCR product. Lanes 1 to 6 : fish showing SD-like symptoms. Lanes 7 to 11 , asymptomatic fish. Lane 12: DNA ladder (Raoul marker, Appligene) reliable routine diagnosic method. In this respect, the RT-PCR is certainly the most appropriate method, since the late detertion of virus in experimentally or naturally infected rainbow trout was only successful using the RT-PCR method.

The neurotropism of the mamalian alphaviruses has been well documented (for a review see Strauss \& Strauss 1994, Griffin 1998). Interestingly, in fish infected by the wild type SDV strain, when the virological method was used to detect the virus in either the fish body or the brain, SDV was recovered from the brain at a longer time post-infection than in the body $(26$ to 41 d.p.i., Fig. 2), and furthermore until 70 d.p.i. using the RT-PCR method (data not shown). Whether or not these results reflect a possible neurotropism of SDV associated with viral persistence remains to be determined.

SPDV isolated from Atlantic salmon (Nelson et al 1995) induces in fish lesions very similar to those induced by SDV. The immune cross-protection between SPDV and SDV in infected rainbow trout has been demonstrated (Boucher et al. 1996), suggesting a very close relationship between SDV and SPDV. This has been recently confirmed by nucleotide sequencing of their respective sub-genomic RNAs (Weston et al. 1999, Villoing et al. 2000). The results obtained in the present study from the SPDV infection trials show that the RT-PCR method is also suitable for the diagnosis of SPDV and SDV as well.

The superiority of the RT-PCR method, compared to the other methods, for the routine diagnosis of SDV or SPDV in the field has been demonstrated since positive results (presence of SDV) were obtained in all the fish farm samples tested, whereas the virological and histological/IHC methods failed to detect the virus. Moreover, lesions induced by a birnavirus, IPNV, and SDV/ SPDV are also very similar, and both virus (IPNV and SDV/SPDV) seem able to co-infect fish (unpubl. result). Thus, in the future, a further step to optimize the RTPCR-based diagnosis method will be to define multiplex IPNV/SDV RT-PCR conditions which will provide an appropriate and not yet available differential tool for diagnosing pancreatic diseases in salmonids (McLoughlin 1997), similar to those which have been it has been successfully designed for other viruses (Wirz et al. 1993).

Acknowledgements. We thank Dr Benoit Thuillier for providing material from fish farms and Claire Arnauld at AFSSA Ploufragan for kindly sequencing RT-PCR products. S.V. is a PhD student supported by grants from AFSSA and INRA. 


\section{LITERATURE CITED}

Blake SL, Schill WB, McAllister PE, Lee MK, Singer JT, Nicholson BL (1995) Detection and identification of aquatic birnaviruses by PCR assay. J Clin Microbiol 33:835-839

Boucher P, Baudin-Laurencin F (1994) Sleeping disease of salmonids. Bull Eur Assoc Fish Pathol 14:179-180

Boucher P, Baudin-Laurencin F (1996) Sleeping disease and pancreas disease comparative histopathology and acquired cross-protection. J Fish Dis 19:303-310

Boucher P, Castric J, Baudin-Laurencin F (1994) Observation of virus-like particles in rainbow-trout Oncorhynchus mykiss infected with sleeping disease virulent material. Bull Eur Assoc Fish Pathol 14:215-216

Boucher P, Le Ven A, Baudin-Laurencin F (1995) Transmission expérimentale de la maladie du sommeil: histologie et caractérisation de l'agent infectieux. Nouv Sci Technol 13: $115-117$

Bruchhof B, Marquardt O, Enzmann PJ (1995) Differential diagnosis of fish pathogenic rhabdoviruses by reverse transcriptase-dependent polymerase chain reaction. J Virol Methods 55:111-119

Castric J, Baudin-Laurencin F, Brémont $M$, Jeffroy $J$, Le Ven A, Bearzotti M (1997) Isolation of the virus responsible for sleeping-disease in experimentally infected rainbow-trout (Oncorhynchus mykiss). Bull Eur Assoc Fish Pathol 17: $27-30$

Gabe M (1968) Techniques histologiques. Masson, Paris

Guillou JP, Merle G, Henault S, Hattenberger AM (1999) Detection of viral hemorrhagic septicemia virus (VHSV) in rainbow trout (Oncorhynchus mykiss) by reverse transcription followed by polymerase chain reaction (Diagnostic validation). Vet Res 30:49-60

Griffin DE (1998) A review of alphavirus replication in neurons. Neurosci Biobehav Rev 22:721-723

Houghton G (1995) Acquired protection in Atlantic Salmon Salmo salar and post-smolts against pancreas disease. Dis Aquat Org 18:109-118

Lannan CN, Winton JR, Fryer JL (1984) Fish cell lines: establishment and characterization of nine cell lines from salmonids. In Vitro 20:671-676

Lopez-Lastra M, Gonzalez M, Jashes M, Sandino AM (1994) A detection method for infectious pancreatic necrosis virus

Editorial responsibility: Jo-Ann Leong,

Corvallis, Oregon, USA
(IPNV) based on reverse transcription (RT)-polymerase chain reaction (PCR). J Fish Dis 17:269-282

McLoughlin M (1997) The differential diagnosis of the major pancreatic disorders of salmonids, a diagnostic challenge. Bull Eur Assoc Fish Pathol 17:205

Miller TA, Rapp J, Wastlhuber U, Hoffmann RW, Enzmann PJ (1998) Rapid and sensitive reverse transcriptase-polymerase chain reaction based detection and differential diagnosis of fish pathogenic rhabdoviruses in organ samples and cultured cells. Dis Aquat Org 34:13-20

Murphy TM, Rodger HD, Drinan F, Gannon F, Kruse P, Korting $W$ (1992) The sequential pathology of pancreas disease in atlantic salmon farms in Ireland. J Fish Dis 15: $401-408$

Nelson RT, McLoughlin MF, Rowley HM, Platten MA, McCormick JI (1995) Isolation of a toga-like virus from farmed Atlantic salmon Salmo salar with pancreas disease. Dis Aquat Org 22:25-32

Nishiziwa T, Mori KI, Nakai T, Furusawa I, Muroga K (1994) Polymerase chain reaction (PCR) amplification of RNA of striped jack nervous necrosis virus (SJNNV). Dis Aquat Org 18:103-107

Péducasse S, Castric J, Thiery R, Jeffroy J, Le Ven A, BaudinLaurencin F (1999) Comparative study of viral encephalopathy and retinopathy in juvenile sea bass Dicentrarchus labrax infected in different ways. Dis Aquat Org 36:11-20

Strauss JH, Strauss EG (1994) The alphavirus: gene expression, replication, and evolution. Microbiol Rev 58:491-562

Suzuki S, Hosono N, Kusuda R (1997) Detection of aquatic birnavirus gene from marine fish using a combination of reverse transcription- and nested PCR. J Mar Biotechnol 5:205-209

Villoing S, Béarzotti M, Chilmonczyk S, Castric J, Brémont M (2000) Rainbow trout sleeping disease virus is an atypical alphavirus. J Virol 74:173-183

Weston JH, Welsh MD, McLoughlin MF, Todd D (1999) Salmon pancreas disease virus, an alphavirus infecting farmed atlantic salmon, Salmo salar L. Virology 256: $188-195$

Wirz B, Tratschin JD, Muller HK, Mitchell DB (1993) Detection of hog cholera virus and differentiation from other pestiviruses by polymerase chain reaction. $\mathrm{J}$ Clin Microbiol 31:1148-1154

Submitted: September 15, 1999; Accepted: November 29, 1999 Proofs received from author(s): February 7, 2000 